\title{
Identitas Sosial Warga Huni Rusunawa
}

\author{
Intan Rahmawati \\ intanr@ub.ac.id \\ Jurusan Psikologi, Universitas Brawijaya, Malang, Indonesia
}

\begin{abstract}
Settlement issues oftenly found in urban areas nowadays is insufficient land for sheltering people as the result of the rapid growth of urban population. Modest rental apartment (rusunawa) is considered solution to meet the high demand of decent housing for middle and low income communities. This research aims to understand the overview of social identities of those who are living in rusunawa using several data collection techniques such as observation, interviews, and focus group discussions. Fifteen informants, who has been residing in rusunawa for at least 3 years, participated in this study. This study showed that residents consider rusunawa as a temporary shelter. This identity gave them a prominent cultural concept namely individualism, with some indicators such as less involvement in reseidents' activities, less sense of caring to their environment and safety, and less sense of pride as residents of rusunawa.
\end{abstract}

Keywords: social identity; rental apartment; environment; behaviour

Permasalahan permukiman yang sering dijumpai di perkotaan saat ini adalah berkurangnya lahan untuk digunakan sebagai tempat tinggal akibat dari pesatnya pertumbuhan penduduk di perkotaan. Rumah susun sederhana sewa (rusunawa) dianggap mampu untuk memberikan solusi tingginya kebutuhan hunian yang layak bagi masyarakat ekonomi menengah ke bawah. Penelitian ini mencoba untuk memahami gambaran identitas sosial warga yang tinggal di rusunawa dengan teknik observasi, wawancara, dan diskusi kelompok terarah. Informan dalam penelitian ini berjumlah 15 orang yang meliputi warga huni yang telah tinggal di rusunawa selama satu periode tinggal (3 tahun). Hasil penelitian ini memperlihatkan warga huni menilai rusunawa sebagai rumah singgah. Pemberian identitas rumah singgah ini memunculkan konsep budaya individualisme yang menonjol. Budaya individualisme ini ditandai dengan keterlibatan warga huni yang masih sedikit pada setiap kegiatan rusunawa, rasa peduli memelihara kebersihan dan keamanan rusunawa yang masih kurang serta kurangnya rasa bangga menjadi penghuni rusunawa.

Kata kunci: identitas sosial; rumah susun; lingkungan; perilaku

Received: January 21, 2018 Accepted: September 14, 2018

How to cite: Rahmawati, I. (2018). Identitas Sosial Warga Huni Rusunawa. MEDIAPSI, 4(2), 76-82. doi: https://doi.org/10.21776/ub.mps.2018.004.02.3

\section{Pendahuluan}

Pengembangan daerah perkotaan dilakukan salah satunya dengan mendirikan rumah susun. Keterbatasan lahan di perkotaan dan diikuti dengan kepadatan penduduk yang semakin meningkat mengharuskan pemerintah memilih alternatif penataan lingkungan dengan mengadakan pembangunan rumah susun sederhana, baik yang bersifat menyewa ataupun hak milik. Pada masyarakat yang mampu menjangkau harga yang tinggi tentunya bukanlah menjadi masalah yang cukup besar memiliki rumah susun sederhana, namun bagi masyarakat yang sulit menjangkau, pemerintah memberikan pilihan rumah susun sederhana sewa.

Undang-undang No. 16 Tahun 1985 Tentang Rumah Susun menjelaskan bahwa pembangunan rumah susun bertujuan untuk memenuhi kebutuhan rakyat terutama yang berpenghasilan rendah, meningkatkan daya guna lahan dan hasil guna tanah dengan 
memperhatikan lingkungan, dan memenuhi kebutuhan untuk kepentingan lainnya bagi kehidupan masyarakat. Pembangunan rumah susun sederhana sewa dipersepsikan bahwa masyarakat hanya menyewa rumah dan tidak perlu membeli tanah, sehingga dapat memberikan kemudahan bagi masyarakat kelas bawah untuk memperbaiki kualitas hidupnya. Masalah yang muncul dari jenis rumah susun ini adalah kurangnya pengawasan dan atau penataan lebih lanjut terhadap bangunan tersebut, seperti banyaknya fasilitas yang tidak dirawat dengan semestinya. Ini disebabkan karena kebiasaan hidup dari warga yang memiliki tingkat ekonomi rendah sehingga seringkali membuat bangunan menjadi tidak terawat. Kesan kumuh yang ditampilkan rumah susun ini berakibat enggannya masyarakat yang lebih mampu untuk menempati rumah susun, sehingga muncullah konsep bangunan rumah susun yang memiliki desain, perawatan, serta kualitas bangunan yang sangat baik namun memiliki harga yang mahal, yakni yang kita kenal dengan sebutan apartemen.

Rumah susun memiliki karakteristik yang berbeda dengan perumahan tidak bersusun (landed house). Beberapa aspek kebutuhan manusia harus dipenuhi guna meminimalisisasi pengaruh negatif bagi masyarakat yang tinggal di rumah susun. Permasalahan yang mungkin muncul dalam suatu usaha pemenuhan kebutuhan akan hunian adalah prioritas tujuan pembangunan yang hanya mencakup capaian target fisik dan mengesampingkan aspek sosial dari sebuah lingkup perumahan. Aspek-aspek sosial, budaya, kesejahteraan ekonomi, tata nilai, dan perilaku manusia juga harus diperhatikan dan dipenuhi. Jika kebutuhan sosial tersebut tidak dipenuhi maka akan berujung pada semakin berkurangnya karakter dan identitas daerah setempat, bahkan berimbas pula pada semakin tipisnya rasa saling berhubungan satu sama lain baik itu antar manusia maupun dengan lingkungannya, inilah yang diistilahkan anomi dan alienasi (Budihardjo, 2006).

Tinggal di rusunawa akan memberikan identitas sosial pada warga huninya. Identitas sosial ini akan melekat pada individu berupa rasa memiliki pada lingkungan tinggal, keterlibatan emosi serta terdapat nilai signifikan pada warga huni terhadap lingkungan tinggalnya sehingga dapat memunculkan harga diri (self esteem) warga huni sebagai komunitas rusunawa.

Melihat latar belakang di atas, maka yang menjadi rumusan masalah dalam penelitian ini adalah bagaimana identitas sosial penghuni rusunawa? Dengan mengambil kasus rumah susun sederhana sewa di Daerah Istimewa Yogyakarta/DIY (Kabupaten Sleman dan Kabupaten Bantul), maka tujuan dari penelitian ini adalah untuk memahami identitas sosial penghuni rumah susun sederhana sewa di DIY.

\section{Metode}

\section{Desain penelitian}

Penelitian ini menggunakan pendekatan kualitatif, yaitu metode penelitian yang berusaha memahami dengan menggambarkan atau melukiskan fenomena yang diteliti secara sistematis, faktual, dan akurat mengenai faktafakta yang diamati (Creswell, 2014). Penentuan kredibilitas dalam penelitian ini dilakukan dengan cara (1) melakukan overview untuk melihat fenomena yang diteliti dengan jawaban informan pada tiap butir dan melihat kembali keterkaitan jawaban antar butir, (2) melakukan identifikasi ciri menonjol secara tepat dalam observasi guna mengurangi berlebihnya informasi, (3) pemeriksaan silang 
dengan membandingkan jawaban responden satu dengan lainnya, dan (4) mendorong terjadinya diskusi antar informan sehingga membantu pengungkapan informan yang jujur terhadap pertanyaan penelitian. Teknik pengumpulan data pada penelitian ini adalah observasi, wawancara, dan diskusi kelompok terarah.

\section{Partisipan}

Sumber data dalam penelitian ini adalah warga rumah susun yang telah menghuni minimal satu periode tinggal (3 tahun). Penelitian ini melibatkan 15 informan dan mengambil lokasi di enam rumah susun yang ada di DIY, terdiri dari tiga rumah susun di Kabupaten Sleman (Dabag, Gemawang, dan Mranggen) dan tiga rumah susun di Kabupaten Bantul (Projo Tamansari I, Projo Tamansari II, dan Projo Tamansari III).

\section{Teknik analisis data}

Pada analisa kualitatif, data akan dianalisis dengan tema-tema yang ditemukan dalam penelitian dengan menggunakan deskripsi jawaban responden tentang identitas sosial sebagai penghuni rusunawa. Temuan penelitian kualitatif berisikan data-data yang diperoleh dari hasil penelitian, disajikan dalam bentuk deskripsi penyataan responden yang telah diorganisasikan ke dalam tema-tema dan kategori. Deskripsi tersebut tidak lain merupakan sumber utama untuk menjawab pertanyaan penelitian melalui proses interpretasi (Giorgi \& Giorgi, 2004). Pada kajian ini akan dijabarkan mengenai gambaran umum problem sosial yang terjadi di rusunawa.

\section{Hasil}

Hasil observasi dan wawancara seperti yang diungkapkan oleh beberapa responden memperlihatkan, meskipun akses dan fasilitas rusunawa telah cukup memenuhi, namun kesadaran dari penghuni untuk ikut terlibat dalam kegiatan yang dilaksanakan di rusunawa masihlah kurang. Kebersamaan dan solidaritas antar penghuni dan pengelola perlu ditingkatkan. Selain itu, masalah kesadaran akan kebersihan dan pencurian juga merupakan kejadian yang seringkali dialami warga rusunawa. Tabel 1 berikut merangkum problem sosial yang terdapat di rusunawa.

Tabel 1

Identifikasi Sosial di Rusunawa

\begin{tabular}{|c|c|}
\hline Rusunawa & Problem sosial \\
\hline $\begin{array}{l}\text { Projo } \\
\text { Tamansari I }\end{array}$ & $\begin{array}{l}\text { Interaksi antara warga blok A dan blok B } \\
\text { belum erat. Warga masih cenderung sulit } \\
\text { untuk ikut diajak terlibat dalam kegiatan } \\
\text { paguyuban. Selain itu, warga masih } \\
\text { memiliki rasa tidak percaya dengan } \\
\text { pengurus paguyuban karena masalah } \\
\text { terdahulu mengenai transparansi anggaran. }\end{array}$ \\
\hline $\begin{array}{l}\text { Projo } \\
\text { Tamansari II }\end{array}$ & $\begin{array}{l}\text { Kebersamaan dan kekeluargaan antar } \\
\text { penghuni sangat erat hanya saja warga } \\
\text { rusunawa sangat membutuhkan variasi } \\
\text { kegiatan untuk paguyuban yang telah aktif. }\end{array}$ \\
\hline $\begin{array}{l}\text { Projo } \\
\text { Tamansari III }\end{array}$ & $\begin{array}{l}\text { Warga kesulitan mengikuti peraturan yang } \\
\text { dibuat oleh pengelola yang berkaitan dengan } \\
\text { masalah teknis, fungsional, dan perilaku. } \\
\text { Terjadi kerenggangan antara warga dan } \\
\text { pengelola. }\end{array}$ \\
\hline Dabag & $\begin{array}{l}\text { Kebersamaan dan gotong royong warga } \\
\text { sangat kurang. Interaksi antar warga masih } \\
\text { bersifat individualis. }\end{array}$ \\
\hline Mranggen & $\begin{array}{l}\text { Kurangnya kebersamaan dan gotong royong } \\
\text { antar warga dan peraturan belum berjalan } \\
\text { dengan baik. }\end{array}$ \\
\hline Gemawang & $\begin{array}{l}\text { Kurangnya kebersamaan dan gotong royong } \\
\text { antar warga dan peraturan belum berjalan } \\
\text { dengan baik. }\end{array}$ \\
\hline
\end{tabular}

Sumber: Hasil olahan data peneliti

Identitas sosial sebagai penghuni rusunawa terbentuk dengan dipengaruhi oleh kemajemukan latar belakang asal penghuni yang bukan hanya dari Daerah Istimewa Yogyakarta saja. Selain itu, hal yang paling terlihat sebagai pembentukan identitas sosial disini adalah persepsi transaksional terhadap 
sistem tinggal di rusunawa itu sendiri yang memberikan dampak sulitnya warga untuk berkumpul dan terlibat dalam pelaksanaan kegiatan yang dilakukan untuk meningkatkan kebersamaan antar penghuni. Proses sosialisasi dalam interaksi sosial ini akan membangun kategori sosial yang berbeda dan bertentangan sebagai kami (ingroup) dan mereka (outgroup) bagi pengelola dan warga huni. Kurangnya kebersamaan, solidaritas, dan keterlibatan penghuni rusunawa terbentuk karena kemajemukan warga huni yang selalu silih berganti, sehingga dalam prosesnya untuk jangka panjang solidaritas yang akan membentuk kohesi sosial membutuhkan waktu yang lebih lama.

\section{Diskusi}

Peraturan Menteri Negara Perumahan Rakyat Nomor 14/PERMEN/M/2007 Tentang Pengelolaan Rumah Rusun Sederhana Sewa menyatakan bahwa rusunawa didefinisikan sebagai bangunan gedung bertingkat yang dibangun dalam suatu lingkungan yang terbagi dalam bagian-bagian yang distrukturkan secara fungsional dalam arah horizontal maupun vertikal dan merupakan satuan-satuan yang masing-masing digunakan secara terpisah, status penguasaannya sewa serta dibangun dengan menggunakan dana Anggaran Pendapatan dan Belanja Negara dan/atau Anggaran Pendapatan dan Belanja Daerah dengan fungsi utamanya sebagai hunian.

Penjelasan undang-undang tersebut memperlihatkan bahwa pembangunan rumah susun sederhana sewa bukanlah semata-mata sebagai bentuk efisiensi penggunaan lahan dengan menerapkan sistem vertikal, namun juga sebagai bentuk kepedulian pemerintah untuk memberikan tempat tinggal yang layak bagi rakyat, sehingga secara tidak langsung, pemerintah juga memiliki rencana pengurangan jumlah pemukiman kumuh yang saat ini dianggap belum memenuhi standar lingkungan yang sehat. Munculnya identitas sebagai lingkungan yang kurang tertata, banyaknya problem sosial, dan berbagai pelanggaran yang terjadi di rusunawa membawa pemahaman tentang identitas sosial para penghuninya.

Teori tentang identitas sosial dipelopori oleh Henri Tajfel pada tahun 1957 dalam upaya menjelaskan prasangka, diskriminasi, perubahan sosial dan konflik antar kelompok. Menurut Tajfel, identitas sosial merupakan bagian dari konsep diri seseorang yang berasal dari pengetahuan mereka tentang keanggotaan dalam suatu kelompok sosial bersamaan dengan signifikansi nilai dan emosional dari keanggotaan tersebut (Lorenz, 2013).

Identitas sosial berkaitan dengan keterlibatan, rasa peduli dan juga rasa bangga dari keanggotaan seseorang dalam komunitas tertentu. Sementara itu, Hogg dan Abrams (1990) menjelaskan identitas sosial sebagai rasa keterikatan, peduli, bangga yang dapat berasal dari pengetahuan seseorang dalam berbagai kategori keanggotaan sosial dengan anggota yang lain, bahkan tanpa perlu memiliki hubungan personal yang dekat, mengetahui atau memiliki berbagai minat. Fiske dan Taylor (1991) menekankan nilai positif atau negatif dari keanggotaan seseorang dalam kelompok tertentu.

Penjelasan tersebut di atas menyimpulkan bahwa identitas sosial merupakan bagian dari konsep diri seseorang yang berasal dari pengetahuan atas keanggotaannya dalam suatu kelompok sosial tertentu, yang didalamnya disertai nilai-nilai, emosi, tingkat keterlibatan, rasa peduli, dan juga rasa bangga terhadap keanggotaannya dalam kelompok tersebut. 
Berdasarkan konsep tersebut, maka identitas sosial ikut membentuk konsep diri seseorang dan menempatkan dirinya pada posisi tertentu dalam hubungan sosial yang kompleks.

Identitas sosial dapat dijelaskan dengan konsep kategori sosial dan kategorisasi sosial. Ellemers, Spears dan Doosje (2002) mengungkapkan kategori sosial sebagai pembagian individu berdasarkan ras, kelas, pekerjaan, jenis kelamin, agama dan lain-lain. Kategori sosial berkaitan dengan keompok sosial yang diartikan sebagai dua orang atau lebih yang mempersepsikan diri atau menganggap diri mereka sebagai bagian satu kategori sosial yang sama. Individu pada saat yang sama merupakan anggota dari berbagai kategori dan kelompok sosial.

Konsep berikutnya adalah kategorisasi sosial dimana terjadi definisi terhadap diri sendiri dan juga terhadap orang lain yang menyebabkan seseorang termasuk dalam kategori sosial tertentu dan tidak termasuk dalam kategori sosial yang lain (Hogg \& Abrams, 1990). Kategorisasi sendiri adalah proses kognitif untuk mengklasifikasikan objek dan peristiwa ke dalam kategori tertentu dan bermakna (Turner \& Giles, 1985; Branscombe, Wann, Noel, \& Coleman, 1993). Proses ini bersifat alamiah, terjadi pada setiap individu dan melalui proses ini individu mampu mengolah berbagai informasi secara otomatis dan tepat. Namun, dalam proses kategorisasi ini, individu cenderung melebihlebihkan persamaan dan kurang melihat perbedaan pada stimulus atau informasi yang diamati (Brewer \& Miler, 1996). Proses keseluruhan ini terjadi dalam interaksi sosial.

Menurut Smith (Lorenz, 2013) fungsi adaptif dari struktur kognitif adalah untuk memperantarai lingkungan dan tingkah laku sebagai bagian dari struktur kognitif. Konsep diri dapat diasumsikan memainkan peran yang sama. Konsep diri memproses informasi yang datang dari lingkungan dan mengatur tingkah laku berdasarkan luaran kognitif yang sesuai dengan kondisi tersebut. Manusia belajar mengatur tingkah laku konsep diri yang berbeda-beda pada situasi yang berbeda-beda pula. Situasi yang berbeda akan mengaktifkan konsep yang berbeda, sehingga stimulus sosial diproses dan tingkah laku sosial dikendalikan dengan cara yang tepat. Hong dkk (2003) mengungkapkan situasi sosial yang mengaktifkan potensi identitas sosial akan menghasilkan efek tingkah lakunya sendiri.

Keberlangsungan dan keseimbangan sistem tinggal di rusunawa tidak lepas pula dari identitas sosial yang dipersepsikan warga dan elemen yang terdapat dalam sistem tinggal tersebut. Identitas sosial di rusunawa ini berkaitan dengan pemahaman terhadap budaya tinggal pada hunian vertikal. Hal ini memperlihatkan satu faktor budaya yang penting untuk dipahami dalam budaya tinggal di rusunawa adalah dimensi individualisme dan kolektivisme. Hofstede (2005) menjelaskan bahwa individualisme merupakan sebuah tatanan sosial yang dikarakteristikkan oleh ikatan emosional antar individu yang longgar. Tatanan yang longgar ini menekankan pada kesadaran "aku" dan kemandirian yang ditandai dengan independensi emosi, inisiatif pribadi, dan bersifat privasi. Lebih lanjut, individualisme adalah budaya yang menekankan gagasan bahwa individu terpisah dan tidak tergantung dengan individu lain, otonom dari ingroup, tujuan pribadi menjadi prioritas di atas tujuan kelompok, serta sikap individu secara personal lebih menentukan perilaku sosial individu daripada norma (Triandis, 1996).

Pada penghuni rusunawa terjelaskan 
identitas individualisme yang terdapat kecenderungan untuk menempatkan identitas individu di atas identitas kelompok. Dalam kerangka ini, tujuan dan hak individu memiliki tema di atas tujuan dan hak kelompok. Demikian pula dengan kebutuhan individu yang menempati posisi di atas kebutuhan kelompok.

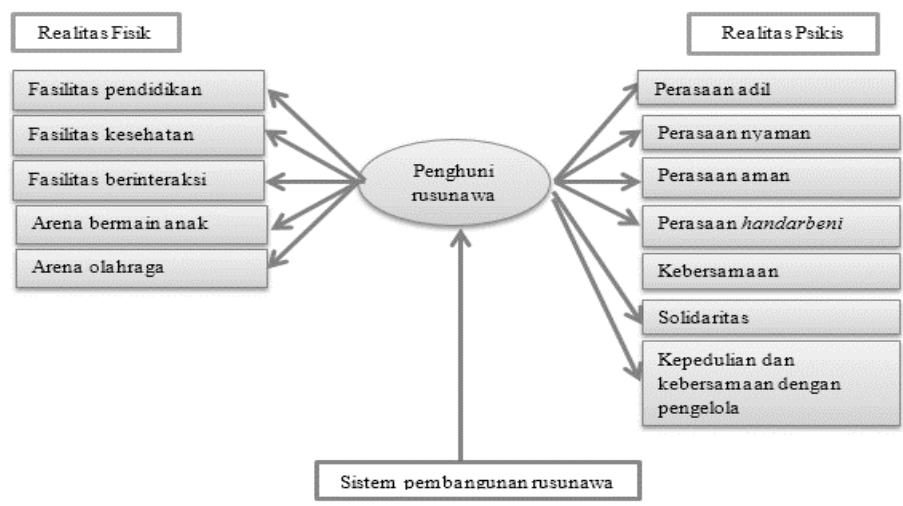

Gambar 1. Realitas Kebutuhan Warga Huni Rusunawa

Gambar realitas kebutuhan warga huni rusunawa seperti yang digambarkan pada Gambar 1 di atas memperlihatkan dua hal yang diperlukan oleh warga huni rusun, yakni kebutuhan yang berkaitan dengan kondisi fisik rusunawa dan kebutuhan psikis yang menyertai sistem tinggal di rusunawa. Hasil pengumpulan data yang telah dilakukan terlihat, interaksi yang terjadi pada warga huni dengan pengelola masih cenderung bersifat transaksional. Seperti yang disampaikan berikut ini:

“...sekarang itu kadang itu, apa ya yang namanya tukang bersih itu kadang ada kadang tidak, jadi lingkungan kurang bersih" (KS2.2d.NA.18-20)

“...diketok kamarnya, ada kalanya mereka mau membersihkan, ada kalanya tidak mau, ada juga yang bilang kita bayar biaya kebersihan kenapa kita harus bersih-bersih sendiri" (KS2.2d.MG.137-139) “...penghuni itu kurang bertanggung jawab, kurang mempunyai rasa memiliki fasilitas umum" (KS2.2d.AN.262-263)

Melihat keadaan tersebut, maka warga huni membutuhkan interaksi yang bernilai kebersamaan atau keguyuban. Faktor budaya Jawa ikut mempengaruhi keinginan warga huni untuk merasakan kebersamaan baik antar sesama warga maupun dengan pengelola. Keberadaan rusunawa di daerah Yogyakarta dengan warganya yang berpegang pada nilai, norma, dan kebiasaan budaya Jawa cenderung menjadi acuan dalam menjalani kehidupan bermasyarakat. Intisari perilaku nilai budaya Jawa di rusunawa diwujudkan dalam paham etika (unggah-ungguh) dan tata hubungannya dengan orang lain sesuai dengan kadar tingkatannya.

Terdapat beberapa hal yang dapat ditarik sebagai kesimpulan dalam penelitian ini, yaitu identitas sosial warga huni rusunawa terbentuk dengan dipengaruhi latar belakang kemajemukan penghuni yang tinggal di rusunawa. Kesamaan pemahaman dan sudut pandang mengenai kemajemukan ini dialami oleh responden di tiap rusunawa. Interaksi yang terjadi di rusunawa membangun kategorisasi sosial sebagai penyewa dan pemberi sewa yakni pengelola. Selain itu, sifat relasi yang transaksional memberikan identitas individualis pada penghuni rusunawa sehingga solidaritas, kebersamaan, dan keterlibatan yang merupakan karakteristik budaya kolektif mengalami penipisan.

Terdapat saran yang dapat diberikan berdasarkan hasil penelitian ini, yakni (1) pihak pengelola menghidupkan pertemuan rutin antar penghuni, karena dengan pertemuan rutin ini diharapkan identitas sosial sebagai suatu komunitas dapat dibangun sehingga dapat mempererat rasa kebersamaan; (2) perlu 
diadakan kegiatan pemahaman budaya tinggal di hunian vertikal bagi penghuni baru rusunawa; dan (3) kepada warga huni diharapkan dapat terus meningkatkan solidaritas dalam bentuk kepedulian antar warga agar suasana tentram di rusunawa dapat tercapai.

\section{Daftar Pustaka}

Branscombe, N. R., Wann, D. L., Noel, J. G., \& Coleman, J. (1993). In-group or outgroup extremity: Importance of the threatened social identity. Personality and Social Psychology Bulletin, 19(1), 381-388.

doi: https://doi.org/10.1177/0146167293194 $\underline{003}$

Brewer, M. B., \& Miller, N. (1996). Intergroup Relation. Buckingham: Open University Press.

Budiharjo, E. (2006). Sejumlah Masalah Permukiman Kota. Bandung: Penerbit Alumni.

Creswell, J. W. (2014). Research Design Fourth Edition. Sage: Los Angeles.

Ellemers, N., Spears, R., \& Doosje, B. (2002). Self and Social Identity. Annual Review of Psychology, 53, 161-168. doi: https://doi.org/10.1146/annurev.psych.5 $\underline{3.100901 .135228}$

Fiske, S. T., \& Taylor, S. E. (1991). Social Cognition. New York: McGraw Hill.

Giorgi, A., \& Giorgi, B. (2004). Phenomenology. Dalam J. A. Smith (Ed.), Qualitative Psychology: A Practical Guide to Research Methods (hal. 86-107). London: Sage Publications.
Hofstede, G. (2005). Cultures Consequences. London: Sage Publications.

Hogg, M. A., \& Abrams, D. (1990). Social Identity Theory: Constructive and Critical Advances. London: Harvester Wheatsheaf.

Hong, Y.-y., Chan, G., Chiu, C.-y., Wong, R. Y. M., Hansen, I. G., Lee, S.-1., . . . Fu, H.-y. (2003). How Are Social Identities Linked to Self-Conception and Intergroup Orientation? The Moderating Effect of Implicit Theories. Journal of Personality and Social Psychology, 85(6), 1147-1160. doi: http://dx.doi.org/10.1037/0022$\underline{3514.85 .6 .1147}$

Lorenz, W. A. (2013). Recognising the face of the other: Difference, identity and community. International Journal of Social Welfare, 22(3), 279-286. doi: https://dx.doi.org/10.1111/ijsw.12027

Triandis, H. C. (1996). The psychological measurement of cultural syndromes. American Psychologist, 51(4), 407-415. doi: $\quad$ http://dx.doi.org/10.1037/0003066X.51.4.407

Turner, J. C., \& Giles. H. (1985). Intergroup Behavior. Oxford: Basil Blackwell. 